\title{
Obituary
}

\section{Gideon Toury}

1942-2016

\section{By Panchanan Mohanty}

Gideon Toury, a scholar of repute, made tremendous contributions to the discipline of Translation Studies. Considering his contributions, it would appropriate to call him one of the founding fathers of Translation Studies. It is important to note that Toury had a strong foothold in translation practice and translation theory. His skills and scholarships are formidable as he exceeded most of his contemporaries in accomplishments. Gideon Toury engaged in practical translation as well as the development of translation theory.

Toury studied at the Tel Aviv University and later taught at it before moving to the University of Leuven. He had won the Hans Christian Andersen Award for his translation of C.S. Lewis's The Voyage of the Dawn Treader into Hebrew. He received an honorary doctorate Middlesex University, London and honorary membership of the UNESCO Chair of Translation Studies at Comenius University, Bratislava, Slovakia. He also served as M. Bernstein Chair of Translation Theory at Tel Aviv University and First Chair Professor in CETRA (Centre for Translation Studies) at the University of Leuven. His seminal works include (a) Translational Norms and Literary Translation into Hebrew in 1977, (b) In Search of a Theory of Translation in 1980, and (c) Descriptive Translation Studies and Beyond in 1995. 


\section{Obituary}

Gideon Toury will be remembered for widening the scope of Translation Studies as an academic pursuit and for foregrounding the socio-cultural approaches to translation. Toury had the pleasure of doing research and co-authoring works with Itamar Even-Zohar and editing books with Roman Jakobson. He initiated the journal Target with Jose Lambert and collaborated with Itamar Even-Zohar for the journal Literature. Toury also served as the editor of the newsletter TRANSST and as vice president of the European Society for Translation Studies. Toury was not keeping well for quite some time. The prolonging ill-health finally culminating into a sad demise has brought an end to his illustrious career on 04 October 2016.

He has led and inspired a generation of researchers in the discipline, and this note is a humble tribute to place on record that his contribution is so phenomenal that both young and established scholars will continue to emulate him in their work. 